DOI: https://doi.org/10.32839/2304-5809/2021-8-96-22

УДК 343.982

Самойлова О.Ф., Печерська I.O.

Харківський науково-дослідний експертно-криміналістичний центр

Міністерства внутрішніх справ України

\title{
ПРОБЛЕМНІ ПИТАННЯ ПРИ ДОСЛІДЖЕННІ ДОКУМЕНТІВ ЗІ ЗМІНЕНИМ ЗМІСТОМ ТЕКСТУ
}

\begin{abstract}
Анотація. Документи різного вигляду та змісту відносяться до об'єктів, які найчастіше надаються на криміналістичне дослідження. Це пояснюеться широким застосуванням їх в різних сфрерах діяльності людини та поширеним використанням в злочинних цілях. Однією з обов'язкових вимог до документу є закріплення його змісту у письмовому вигляді, що може бути виконано рукописним, друкованим або іншим способом, а також за допомогою технічних засобів. Документи - це речові докази, які є носіями матеріальних слідів злочину та інформації про злочинця, тому вони можуть бути використані для розслідування та розкриття злочинів, покарання винних. Дослідження цінних паперів, документів та грошових знаків - один з найбільш складних видів техніко-криміналістичного дослідження, яке потребуе застосування різноманітних спеціальних знань. Під час дослідження цих документів, судовий експерт виділяе, вивчає та оцінюе ознаки, які характеризують об'єкти дослідження. У зв’язку з цим для проведенням всебічного, повного та об'єктивного дослідження судовому експерту-криміналісту необхідно володіти системними та глибокими знаннями у різних галузях науки та техніки, щоб встановлювати способи та ознаки підробки. Ключові слова: документ, техніко-криміналістичне дослідження документів, люмінесценція, методи,
\end{abstract} ознаки підробки, дописка.

Samoilova Olha, Pecherska Irina Kharkov Scientific-Research Expert-Criminalistic Center of the Ministry of Internal Affairs of Ukraine

\section{PROBLEM ISSUES IN THE STUDY OF DOCUMENTS WITH CHANGED TEXT CONTENT}

Summary. Documents of various types and contents are among the objects that are most often submitted for forensic investigation. This is due to their widespread use in various spheres of human activity and widespread use for criminal purposes. Documents, different in form and content, are an integral part of human life and activity. One of the obligatory requirements to the document is to fix its content in writing, which can be done by hand, printed or otherwise, as well as by technical means. Documents are material evidence that are carriers of material traces of the crime and information about the offender, so they can be used to investigate and solve crimes, punish the perpetrators. The study of securities, documents and banknotes is one of the most complex types of forensic research, which requires the application of various specialized knowledge. During the examination, the forensic expert identifies, studies and evaluates the features that characterize the objects of study. Therefore, in order to conduct a comprehensive, complete and objective examination, a forensic forensic expert must have a systematic and in-depth knowledge in various fields of science and technology to establish the methods and signs of forgery. The documents are accompanied by: creation, preservation, circulation of material values; the activity of persons is regulated and registered. They serve as a basis for obtaining material benefits. Therefore, with the advent of documents, the facts of their forgery began to appear. Special protections of documents, laws which are directed on the termination of similar actions of criminals are created. Currently, the number of cases when criminals commit partial or complete forgery of documents, which are most often related to obtaining material goods, is constantly growing. Significant material damage is inflicted on the state and citizens, so to protect the interests of the state, its citizens and create preventive measures to prevent crimes related to forgery, law enforcement agencies carefully study and analyze documents whose content has been amended by criminals. Forensic examination of documents is appointed when it is necessary to find out the method of preparation of the document, what technical means and materials were used; to establish the fact of making any changes in the document, establishing the content of the changed and damaged documents.

Keywords: document, forensic examination of documents, luminescence, methods, signs of forgery, addition to the document.

$\Pi^{2}$ остановка проблеми. Експертна практика свідчить, що при встановленні факту дописки не виключае, а іноді, потребуе участі у дослідженні документа, у відношенні якого $€$ підозра про наявність в ньому змін первинного змісту, судових експертів різного профілю.

Виникае необхідність призначення комплексної експертизи. На практиці при встановленні дописки, вкрай рідка, залучаються експерти, які володіють спеціальними фізичними та хімічними методами дослідження.
Через необізнаність деякими судовими експертами суті явищ, які знаходяться в основі різноманітних методів дослідження, може відбуватися неповне вивчення об'єкта зі зміненим змістом - шляхом дописки. Тому, що судові експерти не завжди можуть відрізнити дослідження об’екта у відображених ультрафріолетових променях від вивчення об’єкта дослідження за допомогою видимої люмінесценції, яка збуджена ультрафріолетовими променями.

Аналіз останніх досліджень і публікацій. Значний внесок у технічне дослідження докумен- 
тів та виявлення способів підробки документів, а саме криміналістичного дослідження документів зі змінами первинного змісту здійснили такі вчені, як: Белкін Р.С., Воробей О.В., Мельник I.М., Волошин О.Г., Яблоков Н.П., Гордон Б.Е., Макаренко В.Я., Розкин М.Я., Микуленко В.В., Павлов Л.В., Селезнев М.М., Слезко Г.Ф., Шевченко Э.А. та багато інших. Проте наукових робіт, безпосередньо присвячених криміналістичному дослідженню документів зі зміненим змістом, останнім часом зустрічається замало.

Виділення невирішених раніше частин загальної проблеми. Під час дослідження документів зі змінами первинного змісту, перед судовими експертами, ініціатори дослідження, ставлять дві основні задачі: це встановлення фракту змін та встановлення первинного змісту документа. Виникає необхідність у подальшій розробці пропозицій та рекомендащій, які можуть використовуватися в практичній діяльності експертів-криміналістів, зокрема, для вдосконалення методики технічного дослідження документів зі зміненим змістом.

Мета статті. Головною метою $е$ формування взаємодії з іншими напрямами судової експертизи (наприклад, почеркознавчої експертизи, експертизи матеріалів документів та інших) при вирішенні поставлених перед судовим експертом запитань у рамках експертного дослідження об'єктів зі змінами первинного змісту. Необхідна співпраця судових експертів-криміналістів 3 судовими експертами-фрізиками та судовими експертами-хіміками при рішенні окремих задач судово-технічної експертизи, зокрема, тих, які вимагають проведення комплексного дослідження та навчити судових експертів-практиків чітко розуміти технічні можливості того чи іншого методу дослідження при вирішенні питань встановлення дописки та оцінці значимості виявлених ознак.

Виклад основного матеріалу. Під документом розуміють: об'єкт, що містить певну інформацію, призначену для передачі у часі та просторі (наприклад, фотоплівка); офіційний, діловий папір, що підтверджує певний оракт, інформацію, право на щось і т. ін.; офріційне посвідчення особи (паспорт і т. ін.).

Документами супроводжуються: створення, збереження, обіг матеріальних цінностей; регулюеться та реєструеться діяльність осіб. Вони служать підставою для отримання матеріальних благ. Тому 3 появою документів почали 3'являтися фракти їх підробки [1, с. 107].

Створені спеціальні захисти документів, закони, які спрямовані на припинення подібних дій злочинщів. У теперішній час кількість фрактів, коли злочинщі здійснюють часткову або повну підробку документів, які найчастіше пов'язані з отриманням матеріальних благ, постійно зростає. Державі та громадянам наноситься значний матеріальний збиток, тому для захисту інтересів держави, її громадян та створення профрілактичних заходів щодо запобігання злочинів, пов'язаних 3 підробкою документів, правоохоронні органи ретельно вивчають, аналізують документи, в зміст яких злочинцями були внесені зміни.

Дослідження цих документів дозволяе: з'ясувати механізм скоєння злочину за допомо- гою підроблених документів; встановити збиток, заподіяний злочинцями; уточнити окремі обставини злочину; надати допомогу у встановленні особи потерпілого (потерпілих); викрити злочинця.

Документи стають речовими доказами в силу конкретних причин або обставин, що викликані діями особи, схильної до правопорушення. Вони повністю або частково втрачають свої фрункщіональні властивості та набувають ознак, що вимагають спеціального вивчення для встановлення ïx ролі, як письмових актів певного призначення в скоєнні злочину або правопорушення, або зв'язків $з$ його обставинами, що викликані діями правопорушника [2, с. 7].

Підставами для віднесення документів до речових доказів можуть бути: перекручення фрактів у правильному по формі документі; невірне зазначення джерела, часу, місця та інших обставин та умов складання документа; наявність ознак, що вказують на штучне виконання тексту, будь то рукописного або друкованого, підпису, відбитків печаток та штампів та інше; зміни, що пов'язані зі способом скоєння правопорушення або злочину та його приховування (підчистки, травлення, дописки і т.д.). Також це можуть бути час, місце та інші обставини виявлення документа, його стан, якщо ці фракти мають значення для кримінального провадження, належність особі, використання документа учасником злочину. Виходячи 3 щих ознак, документи, які пов'язані зі злочином, що розслідуеться, можливо поділити на чотири види речових доказів, а саме:

- документи, що служили знаряддям злочину;

- документи, що зберегли на собі сліди злочинів;

- документи, які були об'єктом злочинних дій;

- документи, що можуть бути засобами для розкриття злочину чи правопорушення, або викрити злочинця чи правопорушника, або пом'якшення вини обвинуваченого.

Техніко-криміналістичне дослідження документів виявляє ознаки змінення їх первинного змісту, можливість встановити залиті, закреслені тексти, розірвані, спалені бланки; виявити ознаки технічної підробки підписів, якими засвідчувалися документи; виявити ознаки відбитків печаток та штампів; встановити систему та конкретний екземпляр друкуючої машини, на якій надрукований досліджуваний текст; виявити спосіб друку та які саме знакодрукуючі засоби використовувалися для друкування тексту.

В розслідуванні злочинів або правопорушень найчастіше правоохоронці мають справу з двома великими групами документів:

- документами - носіями інформації об обставинах, які пов'язані з діями по скоєнню злочинів (писемними доказами);

- документами - речовими доказами.

Криміналістичному дослідженню підлягають офріційні та неофіційні документи. Перші можуть служити для посвідчення будь-яких юридичних фрактів, та є стандартними. Офіційні документи виготовляються у відповідності зі встановленими зразками, їх видають установи, підприемства та організації. Вони містять певні реквізити, без яких вони є недійсними. Реквізитами бланка документа є: його форма, розмір, колір, наявність 
захисних елементів (кольорових волокон, захисних сіток, водяних знаків та тощо), використання способів (друку) нанесення зображень, наявність відбитків печаток та штампів, фротокартки, підписів та інше. Неофіційними документами вважаються ті, що надійшли від приватних осіб. Ці документи можуть бути з відомим джерелом походження (вони мають дату, підпис) і анонімні (без підпису) або складені від імені вигаданої особи. За призначенням вони можуть засвідчувати будь-які права або фракти та певні відомості. Документи поділяються на справжні та підроблені. В свою чергу справжні документи можуть бути дійсними або недійсними (коли термін дії документа закінчився (посвідчення або пропуск) ). Документи, в яких зміст не відповідає дійсності, а реквізити змінені або викривлені, вважаються підробленими.

На судову техніко-криміналістичну експертизу документів надаються документи, які засвідчують особу, в тому числі паспорта громадян України, різного роду посвідчення та свідоцтва, дипломи про закінчення учбових закладів, платіжні відомості, чекові книжки та інше.

Судова техніко-криміналістична експертиза документів призначається, коли необхідно з'ясувати спосіб виготовлення документу, які технічні засоби та матеріали використовувалися; встановити фракт внесення в документ будьяких змін, встановлення змісту змінених та пошкоджених документів. Найчастіше до судових експертів звертаються, щоб з'ясувати та встановити наявність або відсутність змін первинного змісту документа, чи є в наявності на документах підчистки, дописки, травлення або інші сліди фольсифікацій. Змінам піддаються тексти, відбитки печаток та штампів, замінюються аркуші в багатоаркушному документі, фотокартки, марки та тощо. Зміст текстів змінюють найчастіші шляхом дописки, але дописці майже завжди зазвичай передуе підчищення штрихів первинного тексту або знебарвлення штрихів за допомогою хімічних речовин [3, с. 10].

При зміні первинного змісту документа судовий експерт після вирішення першої задачі (коли він встановив фокт дописки конкретних записів), одночасно вирішує другу задачу (встановлює, коли це можливо, первинний зміст документа).

Дописка - це спосіб зміни первинного змісту тексту документа, при якому нові записи вносяться на вільні від тексту місця (на поверхню між строк, слів, цифр та знаків) або на ділянки, де записи були видалені підчисткою або травленням. Такі записи можуть являти собою як смислові фррагменти (слова, букви та цифрри), так і окремі штрихи (елементи букв, цифр або інших позначень), у випадку коли дописуються окремі штрихи судові експерти мають на увазі домалювання, як різновид дописки. Таким чином змінюють прізвище, ім'я, по батькові, рік та місце народження, місце та час реєстрації, термін дії документа та інші дані, коли домалюванням, змінюють первинний зміст тексту шляхом додавання окремих штрихів до знаків (букв , цифр та тощо), схожими по написанню. Таким чином, цифрра «3» переробляеться в циорру «8», а цифра «0» - цифрру «6» або цифру «9». Прикладом до- писки є зміна прізвища, наприклад «Сомов» на «Хомов» шляхом домалювання ліворуч від великої букви «С» напівовалу чи змінення цифр суми «100» на «400» або на «700» домалюванням відповідно вертикального або двох горизонтальних штрихів до цифри «1».

При направленні на судову експертизу документа у відношенні якого є підозра о наявності в ньому зміни первинного змісту шляхом підчистки та нанесенням нових записів на місці підчистки, шляхом дописки, перед судовим експертом ставлять зазвичай наступні запитання:

- Чи мають місце зміни первинного змісту документу, наданого на дослідження?

- Яким способом вносилися зміни в документ, наданий на дослідження?

- Який первинний зміст тексту, в який були внесені зміни?

Вирішення вищезазначених питань потребує насамперед застосування комплексу традиційних методів судово-технічної експертизи документів, таких як загальнонаукових (спостереження, вимірювання, описання, порівняння) та спеціальних (візуального, мікроскопічного та форогорафічного) методів дослідження (у різних режимах освітлення, у видимій і невидимій зонах спектру, світлової мікроскопії, люмінесцентного аналізу, дослідження у відображених інфррачервоних та ультрафріолетових променях, вологового копіювання тощо). При необхідності можливо, а іноді і рекомендуеться використовувати спеціальні фрізичні та хімічні методи аналізу складу матеріалів письма (емісійний, спектральний та рентгенівський аналіз, спектрофотометрії в ультрафіолетовій, видимий та інфрачервоній зоні спектра, паперова та тонкошарова хроматографія, крапельний аналіз тощо).

Не дивлячись на великий арсенал рекомендованих методів, не завжди вдається встановити фракт дописки. Найбільш складна задача для судового експерта виникає, коли первинний зміст змінюють шляхом домалювання окремих елементів. Іноді злочинці або правопорушники при формуванні документа спеціально залишають місце для внесення до тексту подальших змін. При цьому використовують один і той самий писальний прилад та матеріал письма, а дописку відтворює та ж особа, яка виконувала основний текст документа. В цьому випадку вирішити питання дописки занадто складно. Судовому експерту набагато простіше встановити фракт дописки, коли вона (дописка) проводилася особою, яка не виконувала текст всього досліджуваного документа, заздалегідь не було передбачено, використання барвника, що не відрізняється за своїм якісним складом від барвника штрихів основного тексту і особливо в тому випадку, коли ці речовини відносяться до різних родів (класів), наприклад кулькова ручка та ручка 3 чорнилами на гелевій основі.

Особливості дописки, як способу підробки документа $є$ те, що записи, які раніше були в документі зберігаються (не видаляються, не замальовуються та тощо), а зміст цих записів змінюеться за рахунок додавання нових штрихів.

Особа, яка працюе з документом, в який вона вносить зміни шляхом дописки, намагаеться робити це непримітно: ретельно підбирає писальні 
прилади з відповідними барвниками, матеріали письма, схожі з писальними приладами та матеріалами письма, якими виконаний первинний текст досліджуваного документу, дотримується відповідного натиску, який спостерігаеться в первинних записах досліджуваного документу, особливостей розташування записів у документі, знаходить також саму (схожу) підкладку. Однак встановити всі обставини виконання початкових записів у документі важко, особливо, коли дописку виконувала особа, яка не створювала первинний текст. Тому в результаті експертного дослідження встановлюються ознаки, які свідчать про виконання фррагментів документа в різних умовах, які і є ознаками дописки. Дописка не рідко намагаються приховати. Коли є потреба замаскувати дописку чи домалювання, злочинщі або правопорушники намагаються наслідувати почерк виконавця тексту, який знаходиться у документі, підбирають відповідні писальні прилади, барвники, проводять повторне обведення частини або всього тексту документа.

Ефективність застосованих методів та об'єм дослідження, які проводилися судовими експертами, залежать від характеру внесених у документ змін, властивостей барвної речовини, штрихів первинного та нового тексту, умов його виконання.

Для дописаних записів характерно: незвичайне розташування цих записів (знаків та їх елементів) відносно первинного тексту, ліній графлення, країв та полів документу; суміщення лініі строки (піднімаються або опускаються закінчення тексту в строчщі); стислість дописаного тексту в порівнянні з основним текстом; скорочення слів у дописаному тексті за браком вільного місця; зменшення знаків у кінці строки. Наприклад, в платіжних відомостях, в колонках цифрових записів, порушується розташування цифр по розрядам, може спостерігатися викривлення лінії рядка, тощо. Ці ознаки можуть і не проявитися у досліджуваному документі. В цілому висновок судового експерта дається на основі оцінки конкретної сукупності встановлених ознак.

Цінна інформація може бути встановлена при почеркознавчому дослідженні документа, вивченні взаємного розташування частин тексту, визначенні хронологічної послідовності виконання фррагментів документа по штрихам, що перетинаються.

Ознаки дописки - це наявність невідповідностей у реквізитах документа (змісту тексту, підписах, відбитках печаток та штампів, резолюціях); розбіжність почерку в первинному тексті та у дописаній частині. Під час виконання дописки, важко оцінювати загальні ознаки почерку. В загальних ознаках проявляються розбіжності - у розмірі букв, нахилу, а у зв'язності та натиску в меншому ступені. Судовий експерт при дослідженні документа, в якому є ознаки дописки звертає увагу на такі ознаки почерку як уповільнення темпу, що проявляеться в уривчастості виконання письмових знаків та їх елементів, наявності тупих початків і закінчень штрихів, невиправдані, безпідставні зупинки писального приладу, недифреренційованому натиску. Все це нерідко супроводжується зниженням координації рухів першої групи (звивистість, хвилястість штрихів, кутастість овалів, тупі початки і закінчення штрихів).

Винести категоричний висновок та правильно охарактеризувати загальні ознаки наданого на дослідження короткого рукописного запису може бути важко через вкрай обмежений об'єм графічного матеріалу. Під час дослідження ознак почерку необхідні спеціальні знання в галузі почеркознавства, але необхідно враховувати, що розбіжні ознаки почерку можуть з'явитися, коли дописка виконана однією і тією ж особою, але умови письма суттево відрізняються.

Така ознака, як різний ступінь вдавленості штрихів (натиск) може з'явитися при виконанні дописаних записів, як з іншим натиском, так i 3 тим же натиском, але виконанням на іншій підкладці (вона може бути м'яка або тверда). Дослідження дописки при цьому проводиться у косо направленому освітленні, зйомка в токах високої частоти. При цьому важливо вивчити судовим експертом на тільки лицьовий, а і зворотній бік документа.

Така ознака, як зміна ширини штрихів може з'явитися при виконанні дописаних фррагментів та основного тексту різними писальними приладами. Зміна ширини штрихів може бути викликана зміною підкладки, збільшення (зменшення) натиску. Виявити різницю штрихів по ширині можливо за допомогою вимірювальної лупи, мікроскопа, відео-спектральних компараторів.

Під час дослідження штрихів дописки може бути встановлені розбіжності мікроструктури штрихів дописаних фррагментів та штрихів основного тексту. Мікроструктура штрихів обумовлена низкою фракторів, це в першу чергу, склад матеріалів письма, та особливості взаємодії матеріалів письма 3 основою (папером або іншими матеріалами) документа. Наприклад, пасти кулькових ручок в штрихах розподіляються найчастіше не рівномірно, невелика кількість пасти збираеться на пишучому вузлу та залишає на поверхні штрихів згустки. Штрихи, виконані чорнилами, рівномірно забарвлені, мають чіткі краї, по краям можуть спостерігатися мікророзпливи. Графрітний олівець (у відповідності з його твердістю) залишає штрихи у вигляді трас від твердих частинок каоліну, краї таких штрихів чіткі. Тому, коли використовуеться при дописці інший матеріал письма, спостерігається різниця не тільки в кольорі, але і у мікроструктурі штрихів первинних записів та дописок. Мікроструктура штрихів також залежить від особливостей конкретного писального приладу та підкладки. Наприклад, у штрихах виконаних кульковою ручкою, спостерігається специфрічна мікроструктура поверхні пишучого вузла, що обумовлена його будовою. Структура рельефу підкладки чітко відображається у олівцевих штрихах. Коли дописка виконуеться в інших умовах (зміна підкладки, писального прилада), мікроструктура дописаних штрихів буде відрізнятися від штрихів первинних записів, при зміні підкладки можуть з'явитися забруднення зворотного боку досліджуваного документа в місці розташування дописаних штрихів (вона буде або збільшена, або зменшена), але інша ніж в місці розташування первинних записів. Вивчення мікроструктури 
штрихів проводиться з використанням збільшуваних приладів, а саме лупи, мікроскопа, електронних мікроскопів; фріксуеться фотокамерами та відео-спектральних компараторами.

Експертна практика свідчить, що при встановленні фракту дописки $є$ необхідність участі в дослідженні документа у відношенні якого $є$ підозра о наявності в ньому зміни первинного змісту, судових експертів різного продрілю, тобто виконання комплексної експертизи, на практиці при встановленні дописки в край рідка залучаються експерти, які володіють спеціальними фрізичними та хімічними методами дослідження. Не завжди використовуеться комплекс рекомендованих традиційних методів судово-технічної експертизи документів. У результаті чого питання, які ставить слідчий суддя або слідчий перед судовим експертом залишаються не вирішеними, а висновки судових експертів, виходять недостатньо обгрунтованими. Все це відбувається 3 наступних причин: не достатне володіння судовими експертами-практиками загальною методикою вирішення окремих задач судовотехнічної експертизи, зокрема, тих, які вимагають проведення комплексного дослідження за участю судових експертів-фрізиків та судових експертів-хіміків; із-за відсутності чіткого розуміння судовими експертами про технічні можливості того чи іншого методу і невірної оцінки значимості виявлених ознак. Так, недосвідчені експерти, при встановленні дописки, іноді обмежуються дослідженням окремих властивостей матеріалів, якими виконані штрихи. Досліджуючи їх копіювальні, люмінесцентні властивості, їх поглинаючу здібність у відбитих інфрачервоних променях тощо. Іноді виникають конкретні ситуації, коли не встановлюються розбіжності в цих властивостях. Без встановлення розбіжностей робиться недостатньо обгрунтований висновок про відсутність дописки в дослідженому документі, стверджуючи, що барвні речовини мають однаковий якісний та кількісний склад. Це не $є$ допустимим, оскільки, всі барвні речовини, які використовуються при оформленні документів, по своєму складу багатокомпонентні, тобто до їх складу входять барвник (барвники) і безкольорові компоненти (антисептики, згущувачі, розчинники, смоли тощо).

Для встановлення компонентного складу пасти кулькових ручок з однаковим кольором барвника, був проведений експертний експеримент, під час якого було встановлено розбіжності у компонентному складі барвників [4, с. 288].

Для експертного експерименту було взято дві кулькові ручки - умовно позначені - кулькова ручка «А» та кулькова ручка «Б», пасти цих кулькових ручок були висушені, після чого був вивчений їх компонентний склад за допомогою тонкошарової хроматографії, а саме було встановлено, що спирторозчинний блакитний фрталоціаніновий (барвник) у ручці «А» складає - 17,3\% від маси, а у ручці «В» - 19,5\% від маси; жиророзчинний фіолетовий (барвник) «К» спеціальний у ручщі «А» складає - 4,7\% від маси, а у ручці «В» - 5,4\% від маси; бензоловий спирт (розчинник) у ручці «А» складає $-17,8 \%$ від маси, а у ручці «В» - 17,0\% від маси; френілгліколь у ручці «А» складає - 17,8\% від маси, а у ручці «В» - він відсутній; 1.2 - пропіленгліколь - у ручці «А» складае - 5,0\% від маси, а у ручці «В» - 5,0\% від маси; смола Фл-326 у ручці «А» складає - 32,1\% від маси, а у ручці «В»30,9\% від маси; лувіскол К-90 - у ручці «А»-0,3\% від маси; а у ручці «В»-0,2\% від маси; жирна кислота (олеїнова) - у ручщі «А» - 5,0\% від маси, у ручці «В»-5,0\% від маси [5, с. 54].

Як бачимо, склад однокольорових паст «А» та «Б» різниться тільки відношенням компонентів, у той час як якісний склад матеріалів письма однаковий. Незначні розбіги в складі письма відповідно відображаються у властивостях штрихів, які нанесені кульковими пастами «А» та «Б».

Властивості штрихів незначно відрізняються один від одного, що з'ясувати щі відмінності за допомогою традиційних методів судово-технічної експертизи документів надзвичайно складно, а іноді неможливо, хоч фракт дописки мав місце у досліджуваному документі. Тому, якщо у процесі вивчення тексту документа не виявлена різниця в окремих властивостях порівнюваних штрихів записів, недоцільно результати цього дослідження брати за основу висновку про відсутність дописки в досліджуваному тексті.

Коли виявлені розбіжності окремих властивостей порівнюваних штрихів, треба враховувати вплив на результати окремі фактори, так, на картину люмінесценції штрихів впливає не тільки склад матеріалів письма, але і наявність в ньому домішок, особливості розподілу барвної речовини у штрихах записів, умови зберігання досліджуваного документа. Експертна практика доводить, що збільшення щільності барвної речовини у штрихах записів впливає на інтенсивність люмінесценції - відбувається її зниження. Внаслідок цього, необхідно, обережно оцінювати відмінності люмінесцентних властивостей штрихів записів при встановленні фракту домалювання у буквах, цифррах та знаках.

Вологе копіювання, подібне до люмінесцентного аналізу, також доцільно застосовувати при встановленні дописки, оскільки копіювальні властивості штрихів записів залежать від відносної давнини їх виконання та якісного складу матеріалів письма. При оцінці отриманих результатів слід враховувати, що на вологе копіювання впливають, такі фрактори, як доцільний підбір розчинника, рівномірність змочування розчинником поверхні матеріалу, на який будуть копіювати та ступінь рівномірності розподілу сили тиску на копіюючий матеріал. Якщо не дотримуватися цих рекомендацій, можливо дійти до помилкових висновків.

Висновки і пропозиції. Слід зробити висновок, що основною проблемою, яка виникає при дослідженні документів зі зміненим змістом - $є$ встановлення фракту дописки. Бажано залучати судових експертів різного профілю, які володіють: знаннями у галузі почеркознавства, спеціальними фрізичними та хімічними методами дослідження, а іноді в край необхідно це робити, призначаючи комплексну експертизу. Це усуває серйозні недоліки при виконанні судово-технічної експертизи документів зі зміненим змістом, шляхом дописки, що відображаеться на повноті та достовірності висновків судових експертів. 


\section{Список літератури:}

1. Белкин Р.С. Курс криминалистики: т. 3. Средства и методы судебного исследования и предотвращения преступлений. Москва, 1997. 512 с.

2. Воробей О.В., Мельник І.М., Волошин О.Г. Техніко-криміналістичне дослідження документів : навч. посібник. Київ : «Центр учбової літератури», 2008. 304 с.

3. Яблоков Н.П. Техническая экспертиза документов в криминалистике : авторед. дис. ... канд. юрид. наук. Москва, 1954. 120 с.

4. Гордон Б.Е., Макаренко В.Я. Об определении вида красителей чернил. Крилиналистика и судебная экспертиза. Киев, 1971. Вып. 8. С. 288-290.

5. Розкин М.Я., Микуленко В.В., Павлов Л.В., Селезнев М.М., Слезко Г.Ф., Шевченко Э.А. Паста для шариковых авторучек. Рубежанский фбилиал Харьковского политехнического института илени В.И. Ленина. Москва, 1973. С. 66.

\section{References:}

1. Belkin R.S. (1997) Kurs kriminalistiki: t. 3. Sredstva i metody sudebnogo issledovanija $i$ predotvrashhenija prestuplenij [Forensics course: vol. 3. Means and methods of forensic research and crime prevention]. Moskow, 512 p. (in Russian)

2. Vorobey O.V., Melnik I.M., Voloshin O.G. (2008) Tehniko-kriminalistichne doslidzhennja dokumentiv: navch. posibnik [Techniko-kriminalistichne prelijennya dokumentiv: navch. posibnik]. Kyiv: "Center for Educational Literature", 304 p. (in Ukrainian)

3. Yablokov N.P. (1954) Tehnicheskaja jekspertiza dokumentov v kriminalistike: avtoref. dis. ... kan. jurid. nauk [Technical examination of documents in forensic science: avtoref. dis ... kan. jurid. nauk]. Moskow, 120 p. (in Russian)

4. Gordon B.E., Makarenko V.Y. (1971) Ob opredelenii vida krasitelej chernil [On the determination of the type of ink dyes]. Forensic science and forensic examination. Kiev, issue 8, pp. 288-290. (in Russian)

5. Rozkin M.J., Mikulenko V.V., Pavlov L.V., Seleznev M.M., Slezko G.F., Shevchenko J.A. (1973) Pasta dlja sharikovyh avtoruchek [Ballpoint pen paste]. Rubezhanskij filial Harkovskogo politehnicheskogo instituta imeni V.I. Lenina. Moskow, p. 66. (in Russian) 